\title{
Investigating the Moderating Effects of Gender and Self-Efficacy in the Context of Mobile Payment Adoption: A Developing Country Perspective
}

\author{
Mohammed-Issa Riad Mousa Jaradat ${ }^{1} \&$ Khaled M. S. Faqih ${ }^{1}$ \\ ${ }^{1}$ Department of Information Systems / Management Information Systems, Faculty of Prince Hussein Bin \\ Abdullah for Information Technology, Al al-Bayt University, Mafraq, Jordan \\ Correspondence: Mohammed-Issa Riad Mousa Jaradat,Department of Information Systems / Management \\ Information Systems, Faculty of Prince Hussein Bin Abdullah for Information Technology, Al al-Bayt University, \\ Mafraq, Jordan. E-mail: mi_jaradat@aabu.edu.jo
}

Received: July 28, 2014

Accepted: September 1, $2014 \quad$ Online Published: October 22, 2014

doi:10.5539/ijbm.v9n11p147

URL: http://dx.doi.org/10.5539/ijbm.v9n11p147

\begin{abstract}
The adoption rate of mobile payment technology is relatively low in the developing world, particularly in Jordan. The need to study why people in Jordan are unwilling to participate in its adoption is definitely imperative because the outcomes and conclusions of the current analysis could be thoughtfully and strategically utilized to improve and accelerate the adoption and diffusion of mobile payment in Jordan. To achieve this objective, the current study develops a theoretical research model as a framework based on modified Technology Acceptance Model 2 (TAM2). The moderating influence of gender and self-efficacy on the adoption process of mobile payment was integrated in the current model. The quantitative data was collected via a paper-based self-administered questionnaire. A valid 366 data sets (of those just above $50 \%$ are females) were used to assess the model. The model parameters were theoretically analyzed by using the WarpPLS 4.0 software. PLS has been selected on merits because it can statistically handle the complexity of the proposed model. This study has concluded that the perceptions of usefulness and ease of use, subjective norm, output quality, and result demonstrability are all important determining factors of behavioral intention towards mobile payment adoption. Further, image and output quality determinants were empirically observed to influence perceived usefulness construct and indirectly influencing behavioral intention. In the meantime, gender differences were determined to have little moderating influence on the adoption process of mobile payment. However, the self-efficacy aspect was found to have a moderating influence on some of the hypothesized relationships of this model, implying that self-efficacy is a significant decision factor to consider for adoption of mobile payment technology. Moreover, the theoretical and practical implications of the findings and recommendations for future research are presented and discussed.
\end{abstract}

Keywords: mobile payment, technology acceptance model 2 (TAM2), gender, self-efficacy, subjective norm, output quality, result demonstrability, Jordan

\section{Introduction}

During the last three decades, the world has witnessed unparalleled developments in the field of information technology. This global revolution has initiated a radical change in the patterns of how businesses operate and significantly transformed the business environments, making them fast-changing, more turbulent, dynamic, more complex and competitive. So business organizations, especially in western economies, have recognized this technology-driven change, and have substantially invested to make the best use of this technological innovation, such as the Internet and mobile computing, in order to improve their business capabilities and competitiveness. These new technologies are recognized to have caused new waves of innovation to emerge such as mobile commerce (m-commerce). The emergence of novel retailing business channels such as m-commerce has called for the development of new pattern of non-cash electronically-mediated payment instruments to enable feasible, secure and convenient financial transactional activities in these channels (Ondrus \& Pigneur, 2006; Mallat, 2007). This method of payment (mobile payment) is one of the most crucial applications for achieving successful m-commerce technology ( $\mathrm{Lu}$ et al., 2011). Indeed, m-payment is the accelerator of cyber commerce which carries the greatest potentials for fueling mobile computing growth (Hu et al., 2008). Mobile payment is defined 
as the transfer of money through mobile terminals such as mobile phones to make payment for bills, products, services and information (Dahlberg et al., 2008). Mobile payment delivers an array of valuable benefits to consumer. Of those, convenience which offers a fast and straightforward method of payment for goods and services purchased no matter whether they are physical or digital. Also, m-payment is potentially capable of reducing transaction costs which benefits both retailers and consumers (Centre for Economics and Business Research, 2014). According to Forrester Research report (2013) that m-payments in the US will increase to 90 billion dollars in 2017, a compound annual growth rate of 48\% from 2012. According to the same report, this expected increase in the usage of m-payment in the US has been attributed to the fact that m-payment has largely captured the attention and imagination of many interested parties and people. Gartner (2012) reported that global m-payment volume has exceeded 170 billion dollars during 2012, almost 62\% rise from 2011. Also, Gartner expects that worldwide m-payment transactions values to top 617 billion dollars with 448 million users by 2016 , an average compound growth of $42 \%$ annually between 2011 and 2016. Further, Consulting firm KPMG (2012) has forecasted that $\mathrm{m}$-payments will top $\$ 1$ trillion by 2015 , and the value of m-payments will increase around $100 \%$ per year. Apparently, there is a common consent among experts that m-payment technology usage is on the rise in both developed and developing country contexts. Finally, the recent global proliferation of smartphones and other smart devices will apparently enhance the growth of m-payment usage among individuals all over the globe.

This particular technology has recently received a widespread attention from marketers, businesses and research community. Yet, regardless to this large scale attention, the individual acceptance and adoption of m-payment technology have not progressed and proliferated as expected in both developed and developing countries (Bouwman et al., 2012), even though many regions of the world today have already exceeded saturation in terms of mobile-cellular penetration (GSMA Intelligence, 2014). In fact, only marginally m-payment technology has been adopted and used in the US (Hayashi, 2012). Further, a recent report by Advanced Payments Report (2014) has stated that despite the expected enormous potential and promising future, $\mathrm{m}$-payment systems have not yet achieved adequate popularity in terms of adoption and use, with the exception of a few markets particularly in the developing countries. It is apparent that there is a need to conduct focused research from users' perspectives in this field in order to pinpoint factors responsible for deterring potential consumers from adopting and using m-payment channel.

There are no facts and figures readily available to suggest the actual size of m-payment activities in Jordan. Admittedly, it is commonly understood that m-payment in Jordan has yet to take off. However, according to a report released by the Ultimate Middle Ease Business Resource (2014) that m-payment to start in March 2014 in Jordan. Still, the prospect for m-payment technologies to proliferate and expand is high in Jordan for many reasons. First, according to The Jordan Times (2014a), mobile penetration in Jordan stood at $156 \%$ by the end of 2013, with 10.3 million mobile subscriptions. Further, it was reported that Jordan is ranked second in the Arab world in terms of mobile market competitiveness for the second consecutive year (Arab Advisers Group, 2013). However, despite the encouraging statistics regarding mobile phones penetration rate among Jordanians, the rate of m-payment adoption is still in its early stages. Technically, it seems that consumers adoption of m-payment technology is still in its embryonic stages because Jordanians like people of most developed and developing countries are not inclined yet to accept and adopt this technology (Bouwman et al., 2012). Second, 38\% of mobile owners have smartphones in Jordan, according to a report released by The Jordan Times (2014a), as opposed to many Arab countries, Turkey, Russia and China. In fact, the smartphones uptake will continue to grow due the existence of a competitive mobile market environment in the country. Also, according to the same report, Zain Jordan is pushing hard to introduce $4 \mathrm{G}$ wireless network connections in the national carrier by the end of 2014. In addition, Zain Jordan has already provided customers with a highly secured virtual mobile wallet system, which allows them to manage their money with flexibility through mobile devices (The Jordan Times, 2014b). Third, mobile broadband penetration rate in Jordan stands at $36 \%$ by the end of 2013 , while according to International Telecommunication Union (ITU, 2014) forecasted estimates that developing world will reach $20 \%$ mobile broadband penetration rate by the end of 2014. Indeed, the introduction of mobile broadband in Jordan is likely to enhance Internet penetration and increases both online marketing and mobile-based marketing. As a result, the usage of m-payment may likely to explode. Finally, in order to improve the chances of acceptance and adoption of m-payment in Jordan there is a need to study what deters Jordanians from adopting this technology from individual behavior perspectives.

This study is launched to empirically evaluate the moderating effects of gender differences and self-efficacy on m-payment adoption in Jordan. The theoretical framework of the current research is based on a modified Technology Acceptance Model 2 (TAM2). The inclusion of gender in the current study has been triggered by a 
number of issues. First, many prominent scholars have highlighted the impact of gender differences on individual's perceptions and adoption of a new technology. For example, Venkatesh et al. (2000) have considered gender dimension as a salient determinant in technology adoption and usage. Also, according to Gefen and Straub (1997), gender can impact individuals' perceptions and behaviors considerably. As a result, many empirical studies have been carried out to detect the moderating influence of gender on the adoption of information technologies. Indeed, a plethora of researchers have acknowledged the existence of different perceptions and behaviors between males and females with respect to the process of adoption and use of computer and mobile-mediated technologies (Venkatesh et al., 2000; Venkatesh et al., 2003; Lichtenstein \& Williamson, 2006; Zhang, 2009; Jayawardhena et al., 2009; Riquelme \& Rios, 2010; Van Slyke et al., 2010; Wilkowska et al., 2010; Terzis \& Economides, 2011). Second, some studies have revealed inconclusive results and findings regarding the moderating effect of gender on the adoption processes of different IT domains (Venkatesh \& Morris, 2000; Chang et al., 2005; Cyr \& Bonannni, 2005; Zhou et al., 2007; Calisir et al., 2009; Dong \& Zhang, 2011). Apparently, there is a blurred vision from marketing perspective regarding the impact of gender differences on the adoption and acceptance of new technological innovations. Therefore, the moderating role of gender requires further investigation as there has not been consensus on its influence in technology adoption realm. Third, the influence of gender on the adoption of mobile-based technologies and in particular m-payment has not been sufficiently studied, and in developing countries in particular. Also, most empirical findings concerning moderating effects of gender differences on mobile-based adoption processes have been mainly provided by research activities carried out in other countries, more specifically in western cultures. Thus, a significant knowledge gap exists in our understanding of how gender variations impact the adoption of mobile-based technologies in developing country contexts. Consequently, in order to fill this gap, there is an imperative necessity to explore the moderating role of gender in the domain of mobile-based systems such as $\mathrm{m}$-payment in developing country contexts like Jordan which exhibits different culture and values from western nations.

The aspect of self-efficacy with respect to consumers' mobile and online purchasing behavior has emerged as a major determinant in biometric technology adoption and acceptance. The moderation role of self-efficacy on the adoption processes of different IT domains has been inadequately addressed and little insights are available on how consumer's perceived self-efficacy moderates key relationships of adoption theories of behavior such as TAM model and its variants (TAM2, UTAUT, and TAM3). However, the moderation role of self-efficacy has been widely studied in various disciplines outside IT domains (Grau et al., 2001; Schreurs et al., 2010; Werrij et al., 2011; Simosi, 2012; Alessandri et al., 2014). One of a few studies that devoted specifically to the issue of self-efficacy concept demonstrated that self-efficacy has some moderating effects of importance in the adoption process of mobile commerce technology among mobile phone users in a developing country context of Bangladesh (Islam et al., 2011). Apparently, research studies exploring the moderating role of self-efficacy are limited and therefore a significant knowledge gap exists in current literature. One of the major objectives of this study aims at contributing to close this gap. As a result, this study is set to capture empirically the moderating role of perceived self-efficacy on the adoption of m-payment in Jordan through the lens of the Technology Acceptance Model 2 (TAM2).

The rest of this paper is organized as follows: Section 2 presents the theoretical background and research hypothesis of the model. A description of the research model is presented in section 3. Research design and method are presented in section 4. Section 5 presents the results of this study. Finally, section 6 provides discussion of findings, contributions, implications, conclusions and future studies.

\section{Theoretical Background and Research Hypothesis}

\subsection{Technology Acceptance Model (TAM2)}

The Technology acceptance model (TAM) was developed and popularized by Davis et al. (1989) to explain the adoption criteria of a new technology by individual users. Since its inception, the TAM model has been widely applied in research studies related to the investigation of information system adoption and usage. The TAM has introduced two primary constructs, perceived ease of use (PEOU) and perceived usefulness (PU), as bases for explaining adoption process. These two constructs are thought to shape usage behavior from the users' perspectives through behavioral intention to use (BI). Indeed, the two constructs have figured out to be of importance in the adoption studies of different IT domains and various cultural settings. Davis (1989) defined perceived ease of use (PEOU) as referring to "the degree to which a prospective user believes that using a particular system would be free of effort" while perceived usefulness (PU) is defined as "the extent to which a prospective user believes that using a particular system would enhance his or her job performance." However, TAM model has been heavily criticized since it has been applied mostly to voluntary environments with little 
concern for mandatory settings (Chuttur, 2009). Therefore, in order to overcome such shortcomings, the TAM model needs to be extended. TAM2 has emerged as a new variant (see Figure. 1) supposedly applicable in voluntary and mandatory settings (Venkatesh \& Davis, 2000).

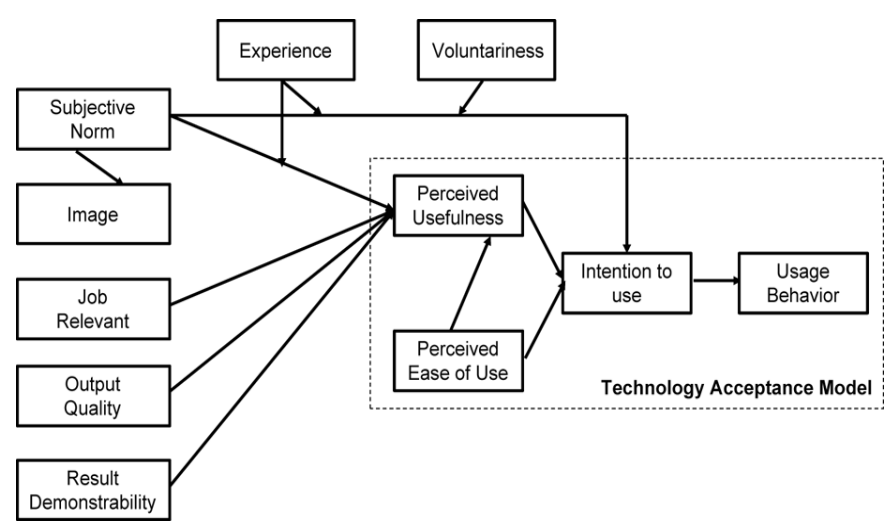

Figure 1. Technology acceptance model 2 (TAM2)

As a matter of fact, acceptance and adoption studies conducted in different social and cultural environments with respect to varying types of technologies have concluded to a large degree that the primary TAM-related relationships are empirically supported with positive significance. Based on this discussion, the following hypotheses are formulated:

$H_{1}$ : Perceived Usefulness has a positive influence on the Behavioral Intention to use m-payment in Jordan.

$\mathrm{H}_{2}$ : Perceived Ease of Use has a positive influence on the Behavioral Intention to use m-payment in Jordan.

$H_{3}$ : Perceived Ease of Use has a positive influence on the Perceived Usefulness to use m-payment in Jordan.

The TAM2 includes two social determinants: subjective norm (SN) and image (IMG). These determinants are considered as having high impact on the perceptions of usefulness (Venkatesh \& Davis, 2000; Venkatesh \& Bala, 2008). Subjective norm refers to the individual's perception that most people who are important to him or her think he or she should or should not perform the behavior in question (Fishbein \& Ajzen, 1975). Venkatesh and Davis (2000) have concluded that subjective norm has a direct positive relationship with perceived usefulness. However, studies conducted in different social settings have reported that subjective norm has some empirical positive influence on behavioral intention (Eze et al., 2011; Sadi \& Noordin, 2011). Specifically, many studies have found that subjective norm is a prime determinant in adoption of technology services provided by mobile devices (Linck et al., 2006; Shin, 2007; Lu et al., 2008; Gu et al., 2009). Similarly, Schierz et al. (2010) analyzed empirically the acceptance of m-payment services; they reported that subjective norm strongly impacts the adoption process of m-payment services among consumers. In the meantime, a number of studies conducted on adoption and acceptance of m-payment systems in various cultural settings have empirically established that subjective norm directly and positively influences behavioral intention to use (Li \& Zhang, 2012; Yang et al., 2012; Yongmeng, 2013; Li et al., 2014; Jaradat \& Al-Mashaqba, 2014). Correspondingly, an empirical study conducted to highlight the factors that influence Chinese consumers to adopt m-payment has demonstrated that the aspect of subjective norm influences behavioral intention (Li et al., 2014). Further, Loch et al., (2003) found that 47 percent of Internet usage in the Arab world explained by social norms.

Image is defined as the degree to which an individual believes that use of a technology will enhance his or her status in a social system (Venkatesh \& Bala, 2008). On reviewing the literature, it is evident that image social aspect positively impacts the perceptions of adoption processes of varying types of information technology systems. For example, according to Teo and Pok (2003), many consumers adopt new mobile services because they enhance their image and social status rather than for functional reasons. Further, Lu et al. (2003) revealed that image has a significant positive effect on acceptance of innovations. The works of Chan and Lu (2004) support the perception that image is an important driver of Internet banking usage. Further, Venkatesh and Davis (2000) concluded that image has a positive influence on perceived usefulness. Also, the TAM2 model conceptualizes that subjective norm will positively and significantly influence image because people believe that performing a behavior will tend to elevate their social status in their social system (Venkatesh and Davis, 2000). 
Indeed, if customers find m-payment can enhance their social image they will be willing to adopt it. Further, prior empirical analysis has concluded that image positively impacts behavioral intention to adopt m-payment technology (Li \& Zhang, 2012; Yang et al., 2012; Jaradat \& Al-Mashaqba, 2014). Based on these arguments, the following hypotheses are established:

$H_{4}$ : Subjective Norm has a positive influence on the Behavioral Intention to use m-payment in Jordan.

$H_{5}$ : Subjective Norm has a positive influence on the Perceived Usefulness to use m-payment in Jordan.

$H_{6}$ : Subjective Norm has a positive influence on the Image to use m-payment in Jordan.

$H_{7}$ : Image has a positive influence on the Perceived Usefulness to use m-payment in Jordan.

\section{$H_{8}$ : Image has a positive influence on the Behavioral Intention to use m-payment in Jordan.}

Furthermore, TAM2 incorporates three system characteristics: job relevance (JR), output quality (OUT), and result demonstrability (RES) (Venkatesh \& Bala, 2008). System characteristics are the features of a system that can help individuals develop favorable (or unfavorable) perceptions regarding the usefulness of a system. However, since the data of this study were drawn from university students therefore job relevant, experience and voluntariness constructs were removed from the model as they have no relevance to the background of the study sample. Output quality is the degree to which an individual believes that the system performs tasks necessary to his or her job (Venkatesh \& Bala, 2008). Many previous studies on adoption of information technologies have empirically confirmed that output quality determinant is positively associated with perceived usefulness (Venkatesh \& Davis, 2000; Pai \& Huang, 2011). This indicates that if potential consumers are contented with the quality of the m-payment system they tend to perceive the system useful. Therefore, m-payment systems must be able to offer sufficient output quality that enhances positively individuals' perceptions of its quality. Based on the concept of TAM theory, whereby perceptions of usefulness are normally translated to behavioral intentions which leading ultimately to actual use of the technology in question, and since output quality aspect has been determined to influence the perceptions of usefulness therefore it is expected that the aspect of output quality will positively influence the behavioral intentions. Result demonstrability which is recognized as the tangibility of the results of using the innovation and it is found to be significant and consistent predictors of perceived usefulness (Venkatesh \& Davis, 2000; Venkatesh \& Bala, 2008). Therefore the system can be recognized having high result demonstrability if it is easy to provide evidence that a system is useful. This indicates that consumers will have more positive perceptions of the usefulness of the technology if positive results are readily discernable. Indeed, the more communicable, tangible, and observable a technology are, the more probable the technology will be readily adopted and accepted (Ong et al., 2008). Furthermore, a study carried out in a developing country context has shown that the system characteristic of result demonstrability has a significant positive association with behavioral intention to use e-banking technology (Njuguna et al., 2012). Therefore, the following hypotheses are proposed:

$H_{9}$ : Output Quality has a positive influence on the Perceived Usefulness to use m-payment in Jordan.

$H_{10}$ : Output Quality has a positive influence on the Behavioral Intention to use m-payment in Jordan.

$H_{11}$ : Result Demonstrability has a positive influence on the Perceived Usefulness to use m-payment in Jordan.

$H_{12}$ : Result Demonstrability has a positive influence on the Behavioral Intention to use m-payment in Jordan.

\subsection{The Moderating Effects of Gender}

The set of characteristics or traits that form socially the most basic dichotomy in human culture is referred to as gender. It is expected that individuals' tendency to make decisions may be driven by their gender types which shapes perceptual perspectives and actions. In fact, the impact of gender on adoption technologies has been acknowledged as an important aspect to pursue for better improving the adoption, diffusion, and proliferation of new technologies among organizations and individuals (Gefen \& Straub, 1997; Venkatesh et al., 2000; Zhang, 2009; Van Slyke et al., 2010). This is why there is a growing body of empirical research focusing on investigating the influence of gender differences on the adoption and use of IT innovations. Indeed, the moderating effect of gender on adoption process of information technologies has been well-established in quite a number of studies (Venkatesh et al., 2000; Venkatesh \& Morris, 2000; Venkatesh et al., 2003; Zhang, 2009; Hasan, 2010; Riquelme \& Rios, 2010). Apparently, research findings reported by studies carried out in different IT domains have clearly revealed its findings have been inconsistent (Cyr \& Bonanni, 2005; Zhou et al., 2007; Calisir et al., 2009; Dong \& Zhang, 2011). Further, some studies have concluded that gender effects were of little significance on the adoption and acceptance processes of a new innovation (Bigne et al., 2005; Zhou et al., 2007; Calisir et al., 2009; Lip-Sam\& Hock-Eam, 2011). This justifies the position of Marchewkaet al. (2007) in their 
study that the moderating effect of gender on behavioral intention to use a technology varies from one domain to another. Still though, there are a limited number of research studies investigating the moderating role of gender in the domain of technology acceptance of m-payment.

In literature, there is clear evidence that men are more likely to adopt a new technology than women, in particular those technologies related to purchasing activities provided by virtual environment since they are characterized by some degree of complexity, uncertainty, increased risk, and untrustworthiness. Also, it is well-documented in literature that different genders are motivated by different motives to carry out a certain behavior. Men are motivated by achievement-related tasks, whereas women value the perception of ease of use (Venkatesh \& Morris, 2000). Correspondingly, many empirical studies were conducted on different information technologies have confirmed that men are more motivated by the usefulness of the technology (Gefen \& Straub, 1997; Venkatesh \& Morris, 2000; Venkatesh et al., 2003; Ong \& Lai, 2006 ; Sun \& Zhang, 2006; Shin, 2009; Zhang, 2009; Hasan, 2010; Van Slyke et al., 2010; Terzis and Economides, 2011), while women are highly motivated and influenced by the perceptions of ease of use (Venkatesh \& Morris, 2000; Venkatesh et al., 2003; Ong \& Lai, 2006; Amin, 2007; Zhang, 2009; Riquelme \& Rios, 2010; Goh, 2011; Terzis \& Economides, 2011). Also, the influence of perceived ease of use on perceived usefulness to adopt and use a technology is stronger for women than men, this has been established by a number of empirical studies conducted on different IT application domains (Venkatesh et al., 2003; Ong \& Lai, 2006; Terzis \& Economides, 2011). Furthermore, it has been firmly concluded by a plethora of research studies that women are more influenced by subjective norm than their men counterparts (Venkatesh \& Morris, 2000; Venkatesh et al., 2003; Riquelme\& Rios, 2010; Terzis \& Economides, 2011; Hamza \& Shah, 2014). Based on these arguments, the following hypotheses are suggested:

$H_{13}$ : Perceived usefulness influences Behavioral Intention to use m-payment in Jordan more strongly for women than for men.

$H_{14}$ : Subjective Norm influences Behavioral Intention to use m-payment in Jordan more strongly for women than for men.

$H_{15}$ : Subjective Norm influences Perceived Usefulness to use m-payment in Jordan more strongly for women than for men.

$H_{16}$ : Image influences Perceived Usefulness to use m-payment in Jordan more strongly for women than for men.

$H_{17}$ : Output Quality influences Perceived Usefulness to use m-payment in Jordan more strongly for men than for women.

$H_{18}:$ Result Demonstrability influences Perceived Usefulness to use m-payment in Jordan more strongly for men than for women.

$H_{19}:$ Perceived Ease of Use influences Behavioral Intention to use m-payment in Jordan more strongly for men than for women.

$H_{20}:$ Perceived Ease of Use influences Perceived Usefulness to use m-payment in Jordan more strongly for men than for women.

\subsection{The Moderating Effects of Self-Efficacy}

Self-efficacy (SE), when applied to the mobile domain, is defined as the degree to which an individual believes that he or she has the ability to organize and execute courses of action to accomplish a particular task/job using mobile device (Compeau \& Higgins, 1995). Indeed, since m-payment phenomenon is more complicated to use than other IT applications therefore mobile-related self-efficacy becomes a fundamentally important aspect in influencing customers' behavior towards its adoption. The construct of self-efficacy has been extensively researched as an independent variable in a wide variety of mobile-based adoption studies and found to be largely influential such as acceptance of mobile health services (Sun et al., 2013), adoption of mobile learning (Lu \& Viehland, 2008; Bao et al., 2013), mobile data service adoption behavior (Yang, 2010), SMS advertising (Zhang \& Mao, 2008), and broadband technologies adoption (Sim et al., 2012). In the Jordanian context, a study conducted by Khraim et al. (2011) confirmed that self-efficacy was an important determinant in the adoption of mobile banking services. According to Bandura (1997), self-efficacy makes a difference in how individuals feel, think, motivate themselves and act. As a result, one's sense of self-efficacy is expected to play an influential role in the pre-intentional phase of behavior towards technology adoption (Suls \& Wallston, 2008). Drawing on self-efficacy theory, low level of self-efficacy can hamper the motivation to adopt a technology like m-payment. In the meantime, individuals with high self-efficacy tend to be positive, confident, deeply committed and motivated to exert a greater effort to accomplish specific objectives (Bandura,1997), and therefore a strong sense of perceived self-efficacy enhances positive perceptions and orientations that drive consumers' adoption and 
usage of a technology like m-payment.

To date, little attention has been paid to examine the moderating role of self-efficacy in mobile-based applications such as m-payment. However, there are a few studies investigating the moderating role of self-efficacy in virtual purchasing environment. For example, Yang (2012) empirically investigated the moderation influence of self-efficacy on mobile shopping adoption using an extended Theory of Planned Behavior (TPB) model. The study confirmed that self-efficacy moderates the positive relationship between perceived enjoyment and attitude towards mobile shopping adoption. Yang's study has also demonstrated that self-efficacy exerts a positive moderation between perceived behavioral control and intention to adopt mobile shopping. Another study conducted by Iconaru (2013) highlighting the importance of self-efficacy as a moderator in the context of online shopping domain. It is clearly apparent from these results that individuals with strong sense of self-efficacy will have stronger perceptions of enjoyment and behavioral control towards adoption of mobile shopping. Further, having high self-efficacy can impact positively consumers' intention to adopt a technology because consumers feel that they are technically in control of the adoption process more than consumers with low degree of self-efficacy. Therefore, owning to the fact that studies exploring the moderating role of self-efficacy in mobile-based applications and other IT domains using TAM2 model are almost non-existent and in accordance with the findings concluded above, the moderating effects of self-efficacy in the relationships among primary TAM2 constructs are investigated with the following hypotheses:

$H_{21}$ : For individuals with a higher level of Self-efficacy, Subjective Norm has a stronger effect on Behavioral Intention to use m-payment in Jordan than those with a lower level of Self-efficacy.

$H_{22}$ : For individuals with a higher level of Self-efficacy, Subjective Norm has a stronger effect on Perceived Usefulness to use m-payment in Jordan than those with a lower level of Self-efficacy.

$H_{23}$ : For individuals with a higher level of Self-efficacy, Image has a stronger effect on Perceived Usefulness to use m-payment in Jordan than those with a lower level of Self-efficacy.

$H_{24}$ : For individuals with a higher level of Self-efficacy, Output Quality has a stronger effect on Perceived Usefulness to use m-payment in Jordan than those with a lower level of Self-efficacy.

$H_{25}$ : For individuals with a higher level of Self-efficacy, Result Demonstrability has a stronger effect on Perceived Usefulness to use m-payment in Jordan than those with a lower level of Self-efficacy.

$H_{26}$ : For individuals with a higher level of Self-efficacy, Perceived Ease of Use has a stronger effect on Perceived Usefulness to use m-payment in Jordan than those with a lower level of Self-efficacy.

$H_{27}:$ For individuals with a higher level of Self-efficacy, Perceived Usefulness has a stronger effect on Behavioral Intention to use m-payment in Jordan than those with a lower level of Self-efficacy.

$H_{28}$ : For individuals with a higher level of Self-efficacy, Perceived Ease of Use has a stronger effect on Behavioral Intention to use m-payment in Jordan than those with a lower level of Self-efficacy.

\section{Research Model}

The present study uses a modified Technology Acceptance Model 2 (TAM2) and incorporates self-efficacy and gender as moderating factors. The research model tested in this study is shown in Figure 2. 


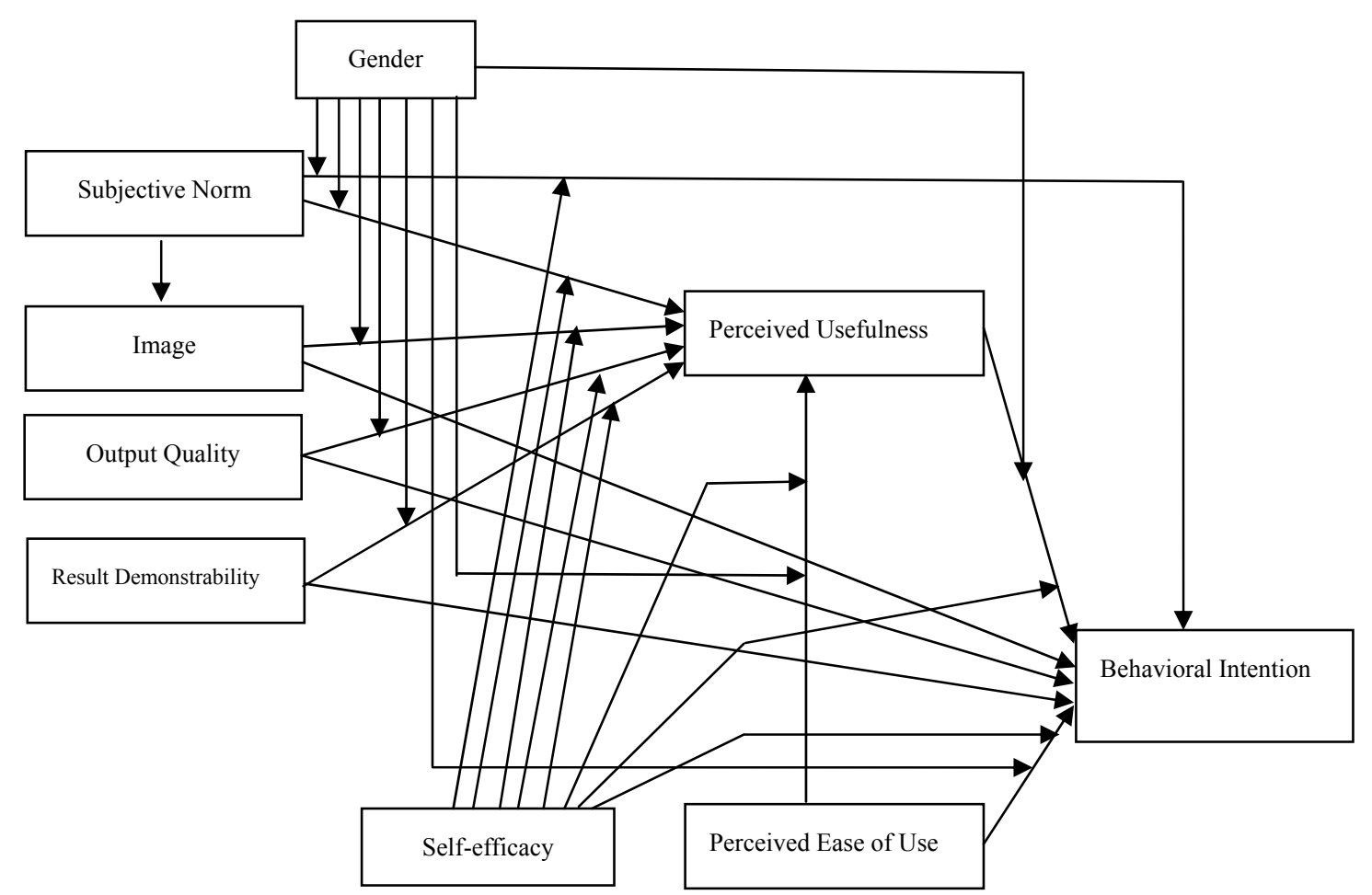

Figure 2. The research model

\section{Research Design and Method}

\subsection{Population and Sample}

This study was conducted at several public Jordanian universities. The data was randomly collected from undergraduate students through paper-based self-administered survey questionnaire by using a stratified random sample. According to Yap and Hii (2009), who argued that because of income and educational level considerations, college students are more likely to be the potential adopters of a new technology such as m-payment. Furthermore, students are mobile savvy which make them feel fairly comfortable using mobile phones for various applications such as getting ubiquitous access to social media. In addition, public universities in Jordan normally enroll students of various socio-economic and cultural backgrounds. Therefore demographic variations among respondents may result in different orientations and perceptions towards m-payment adoption process. According to Sekaran (2006), a sample of 400 students was selected for this study.

\subsection{Measuring the Constructs}

The questionnaire was developed to achieve the objectives of this study. The questionnaire consists of multiple items and its organization based on seven groups. All measurement items are measured on a seven-point Likert scale ranging from: (1) strongly disagree to (7) strongly agree. A 7-point Likert scale gives more variance and provides respondents with a broader range of options, and also it allows for more rigorous analysis than 5-point Likert scale (Hussey \& Hussey, 1997). Measurement items used in the current research study were adapted from a measure that has been previously validated and used by other researchers and studies in the field (Davis, 1989; Venkatesh et al., 2003; Venkatesh \& Bala, 2008). Appendix A presents a list of items for the study constructs. These measures were thoroughly tested by a panel of Information Systems /Information Technology experts for content validity and reliability of each item. The survey was given to a number of referees. The questionnaire statements were modified and amended in accordance with the results and recommendations of the referees, specifically the general information and the translation of the survey statements from English into Arabic.

\subsection{Data Collection Procedure}

A quantitative methodology approach has been utilized to test the proposed model. The questionnaire was 
distributed to a representative sample of students. All participants were selected randomly from public universities in Jordan by using a stratified random sample approach.

\subsection{Data Analysis}

The data for this research has been collected by using a questionnaire containing 29 questions. After the follow-up activities from 400 respondents, 376 returned the questionnaires. Because of incomplete answers, ten questionnaires were dropped from the analysis. This left with 366 valid data sets (186 of the respondents are female) for statistical analysis, with a valid return rate of $91.5 \%$. The structural equation modeling (SEM) using the WarpPLS 4.0 software was used for data analysis. The WarpPLS 4.0 applies the partial least squares (PLS) based SEM technique (PLS-SEM). WarpPLS 4.0 software is a powerful statistical tool because it has added seven new model fit and quality fit indices on the previous version of WarpPLS 3.0 which has already three fit indices: Average path coefficient (APC), average r-squared (ARS) and average variance inflation factor (AVIF), bringing the total to ten indices. The new model fit and quality indices added to WarpPLS 4.0 are average adjusted R-squared (AARS), average full collinearity VIF (AFVIF), Tenenhaus GoF (GoF), Sympson's paradox ratio (SPR), R-squared contribution ratio (RSCR), statistical suppression ratio (SSR), and nonlinear bivariate causality direction ratio (NLBCDR) (Kock, 2013). The PLS-SEM was favorably selected in this study because it is better suited for complex models with large number of constructs and links (Pavlou \& Fygenson, 2006; Ahuja et al., 2007; Au et al., 2008) and equally important PLS-SEM is more suitable than other statistical tools for testing the effects of moderators (Pavlou \& Sawy, 2006; Limayem et al., 2007), as in the case of the current study. Further, WarpPLS 4.0 is equipped with measures related to the quality of the model, such as the ten powerful goodness-of-fit indices, p-values and multi collinearity estimates (Kock, 2013).

\subsection{Reliability and Validity}

The reliability and validity of measurements instrument were assessed through WarpPLS 4.0, these important statistical issues are conducted by assessing the convergent validity and reliability of each measure, and followed by the discriminant validity. The convergent validity and reliability aspects have been evaluated by the combination of factor loading, Cronbach's alpha, composite reliability (CR), and average variance extracted (AVE) as shown in the Table 1. The factor loading measures the strength of the linear correlation between the measuring items and the latent variable. The analysis of the current study shows that all factor loadings are ranging from 0.68 to 0.90 , which exceeds the required threshold of 0.60 (Goffee, 1996). In fact, high factor loadings indicate excellent convergent validity (Fornell \& Larcker, 1981). Cronbach's alpha was used to examine the internal consistency (reliability) of the scale measurement items and research variables for the population study. The results for Cronbach's alpha presented in Table 1 suggest that all measures in this study, ranged from 0.67 to 0.85 , are reliable as recommended by Hair et al. (2003), and well above the required threshold of 0.6 (Goffee, 1996). In order to validate the measurement model, convergent validity was assessed by investigating composite reliability and average variance extracted (AVE) values from the measures. Chin et al. (2003) had suggested that acceptable values for composite reliability should be above 0.70 , and this minimum value of composite reliability estimate has also been recommended and used by most studies in the field. Indeed, the current study has reported that composite reliability values for all variables of the model are exceeding the recommended value of 0.70 . Also, AVE measured values should be greater than the generally accepted cut-off value of 0.50 , it means that $50 \%$ or more of the items' variance should be accounted for (Fornell \& Larcker, 1981). Table 1 shows that all variables of the current model have achieved AVE values above the minimum recommended value of 0.50 . Apparently, all values for composite reliability and AVE calculated in this study meet the recommended threshold values. In conclusion, the statistical analyses obtained here are suggesting that the model exhibits adequate convergent validity and reliability. With regard to discriminant validity, the AVE value for each variable in the current model was computed to test discriminant validity (Campbell, 1960). As shown in Table 1, the square root of AVE for each variable is greater than the correlations between the variable and all other latent variables, demonstrating that all variables of the current model have adequate discriminant validity (Fornell \& Larcker, 1981). However, the factor loadings for all measurement items in the current model were significant and ranging from 0.68 to 0.90 , the high factor loadings are an indication of possible multicollinearity. Therefore, a statistical test of importance called the multicollinearity test has to be performed whenever factor loadings are exceeding 0.70 value (the threshold for possible multicollinearity). By definition, the multicollinearity is a measure of the correlation between the predictors of a variable which falsely inflates the standard errors, and therefore certain model parameters may sometimes become unstable (Kock, 2011). To assess the degree of multicollinearity, variance inflation factors (VIFs) are evaluated for each of the predictor variables. VIFs lower than 5 suggest no multicollinearity (Hair et al., 2009). Table 1 summarizes the results. It is clear that VIFs values meet the recommended threshold values which points to the nonexistence of multicollinearity 
among the predictors of this model. More on this, it is important to examine also both AVIF and AFVIF calculated values (see Table 2) to further affirm the absence of multicollinearity. The current statistical analysis computed that AVIF and AFVIF values are 1.88 and 2.071 respectively which are less than the more restrictive threshold value of 3.30 (Petter et al., 2007; Cenfetelli \& Bassellier, 2009). Finally, based on the estimated statistical parameters of this model, this study demonstrates that the current model exhibits adequate reliability and construct validity which makes the model liable for further statistical analysis such as hypothesis testing.

Table 1. Alpha coefficients, composite reliability, VIF, AVE, and correlation of the constructs values

\begin{tabular}{llllllllllll}
\hline \multicolumn{1}{c}{ Variable } & $\begin{array}{l}\text { Alpha } \\
\text { Coefficients }\end{array}$ & $\begin{array}{l}\text { Composite } \\
\text { Reliability }\end{array}$ & VIFs & AVE & $\mathbf{1}$ & $\mathbf{2}$ & $\mathbf{3}$ & $\mathbf{4}$ & $\mathbf{5}$ & $\mathbf{6}$ & $\mathbf{7}$ \\
\hline 1 Subjective Norm & 0.671 & 0.802 & 1.258 & 0.504 & $\mathbf{0 . 7 1 0}$ & & & & & \\
2 Image & 0.808 & 0.887 & 1.500 & 0.723 & 0.263 & $\mathbf{0 . 8 5 0}$ & & & & \\
3 Output Quality & 0.765 & 0.864 & 1.861 & 0.680 & 0.310 & 0.426 & $\mathbf{0 . 8 2 5}$ & & & & \\
4 Result Demonstrability & 0.770 & 0.854 & 2.023 & 0.598 & 0.338 & 0.445 & 0.521 & $\mathbf{0 . 7 7 3}$ & & & \\
5 Perceived Usefulness & 0.848 & 0.898 & 2.960 & 0.688 & 0.233 & 0.359 & 0.402 & 0.398 & $\mathbf{0 . 8 3 0}$ & & \\
6 Perceived Ease of Use & 0.850 & 0.899 & 2.600 & 0.692 & 0.231 & 0.278 & 0.379 & 0.377 & 0.732 & $\mathbf{0 . 8 3 2}$ & \\
7 Behavioral Intonation & 0.847 & 0.908 & 2.065 & 0.767 & 0.320 & 0.328 & 0.472 & 0.449 & 0.598 & 0.556 & $\mathbf{0 . 8 7 6}$ \\
\hline
\end{tabular}

Note. Square roots of the AVE are the bolded diagonal values.

\section{Results}

The model includes 29 items describing seven latent constructs: Subjective Norm, Image, Output Quality, Result Demonstrability, Perceived Usefulness, Perceived Ease of Use, and Behavioral Intention (see Figure 2). The structural equation modeling (SEM) using the WarpPLS 4.0 software was used to provide the necessary analysis to serve the objectives of this study. The measurement model test resulted in statistically accepted goodness of fit between the data and the proposed measurement model. The various goodness-of-fit statistics are shown in Table 2. Consequently, in accordance to Kock (2013), the model has a good fit to the data.

Table 2.Model evaluation overall fit measurement

\begin{tabular}{lll}
\hline Measure & Value & P-values \\
\hline Average path coefficient (APC) $(<0.05)$ & 0.112 & $\mathrm{P}=0.004$ \\
Average R-squared (ARS) $(<0.05)$ & 0.365 & $\mathrm{P}<0.001$ \\
Average adjusted R-squared (AARS) & 0.352 & $\mathrm{P}<0.001$ \\
Average block VIF (AVIF) & 1.880 & Good if $<=5$, ideally $<=3.3$ \\
Average full collinearity VIF (AFVIF) & 2.071 & Acceptable if $<=5$, ideally $<=3.3$ \\
Tenenhaus GoF (GoF) & 0.474 & Small $>=0.1$, medium $>=0.25$, large $>=0.36$ \\
Sympson's paradox ratio (SPR) & 0.786 & Acceptable if $>=0.7$, ideally $=1$ \\
R-squared contribution ratio (RSCR) & 0.910 & Acceptable if $>=0.9$, ideally $=1$ \\
Statistical suppression ratio (SSR) & 0.893 & Acceptable if $>=0.7$ \\
Nonlinear bivariate causality direction ratio (NLBCDR) & 0.732 & Acceptable if $>=0.7$ \\
\hline
\end{tabular}

Figure 3 presents the significant structural relationships among the research variables and the standardized path coefficients with their respective significance levels. Only 12 of 28 hypotheses proposed are found significant. The hypotheses $\left(\mathrm{H}_{1}, \mathrm{H}_{2}, \mathrm{H}_{3}, \mathrm{H}_{4}, \mathrm{H}_{6}, \mathrm{H}_{7}, \mathrm{H}_{9}, \mathrm{H}_{10}, \mathrm{H}_{12}, \mathrm{H}_{24}, \mathrm{H}_{26}\right.$, and $\left.\mathrm{H}_{27}\right)$ are strongly supported. However $\left(\mathrm{H}_{5}, \mathrm{H}_{8}\right.$, $\mathrm{H}_{11}, \mathrm{H}_{13}, \mathrm{H}_{14}, \mathrm{H}_{15}, \mathrm{H}_{16}, \mathrm{H}_{17}, \mathrm{H}_{18}, \mathrm{H}_{19}, \mathrm{H}_{20}, \mathrm{H}_{21}, \mathrm{H}_{22}, \mathrm{H}_{23}, \mathrm{H}_{25}$, and $\mathrm{H}_{28}$ ) are not supported. The model has explained substantial variance in both perceived usefulness $\left(\mathrm{R}^{2}=0.61\right)$ and image $\left(\mathrm{R}^{2}=0.71\right)$ constructs, and the current model has also explained some $41 \%$ variance in behavioral intention to adopt and use m-payment in Jordan. 


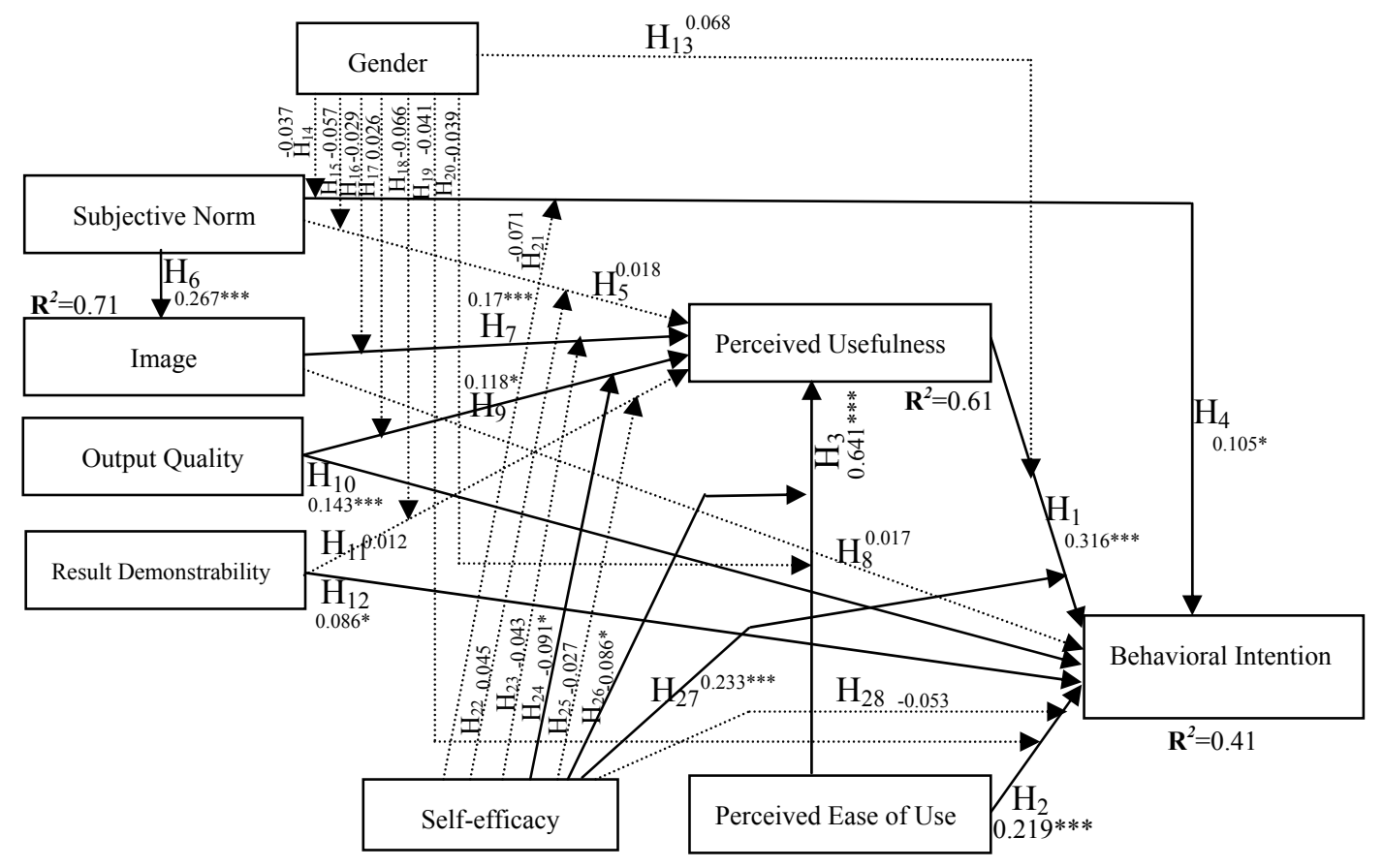

Figure 3. Results of testing hypotheses

Significance at $\mathrm{p}<* * *: 0.001,{ }^{* *}: 0.01, *: 0.05$.

Note. Dotted lines indicate non-significant paths.

\section{Discussion and Conclusions}

\subsection{Discussion of Results}

Motivated by the explanatory and predictive of power of TAM2, this study has been launched to investigate the adoption process of m-payment technology among university students in a developing country context of Jordan. Also, in the light of this study, the moderating influence of both self-efficacy and gender differences have been tested among the majority of the relationships hypothesized in the current study. Further, this study intends to examine the applicability and adaptability of the extended technology acceptance model (TAM2) in the Jordanian context within the m-payment domain. Indeed, to our knowledge, these types of analysis are missing from the literature from both developed and developing country perspectives. The empirical findings and conclusions of the current study offer many important perspectives and insights to the mobile-based systems adoption literature.

The findings of this study support the primary TAM-related hypotheses. This indicates that the TAM model is fully applicable to explain the individuals' acceptance of m-payment in the Jordanian context. TAM model applicability has been also established in the Jordanian context with respect to other IT domains such as online shopping (Faqih, 2011; Faqih, 2013). The empirical outcomes of this study clearly point out that perceived usefulness and perceived ease of use determining variables have a significant positive influence on behavioral intention to use m-payment systems in Jordan $\left(\mathrm{H}_{1}, \mathrm{H}_{2}\right)$. These results correspond with findings and conclusions of many prior research studies (Pousttchi \& Wiedemann, 2007; Kim et al., 2010; Yongmeng, 2013; Tan et al., 2014). However, in the context of this study, perceived usefulness is found to be the most significant predictor of behavioral intention to use m-payment followed be perceived ease of use. Evidently, the current conclusions provide empirical evidence that consumers would be more willing to adopt m-payment technology if they find it useful and easy to use. Also, there is a highly significant positive correlation between perceived ease of use and perceived usefulness $\left(\mathrm{H}_{3}\right)$, suggesting that customers who recognize that m-payment to be effortless and easy to use also perceive it to be efficient and more useful. Many previous studies have drawn similar outcomes and conclusions (Pousttchi \& Wiedemann, 2007; Kim et al., 2010; Schierz et al., 2010; Yongmeng, 2013; Li et al., 2014; Liébana-Cabanillas et al., 2014). Apparently, the current findings confirm the importance of both perceived ease of use and perceived usefulness constructs in predicting individuals' acceptance of m-payment 
technology since they are significantly correlated with the individuals' behavioral intention towards the adoption of m-payment technology. Therefore, it is extremely necessary to understand how these key constructs can be enhanced in the minds of potential customers in order to improve positively their perceptions towards the adoption process of mobile payment technology.

The subjective norm is a social determinant which has figured in various areas of IT domains to be of paramount importance in driving consumers towards adoption of a new technology, particularly in collectivist cultures like Jordan. The current study reinforces the important role subjective norm plays in the adoption process of m-payment technology in Jordan, whereas the present analysis demonstrates that subjective norm is statistically correlated with individuals' behavioral intention to use m-payment. Many studies have reported similar findings (Schierz et al., 2010; Li et al., 2014). Further, in contrary to what has been conceptualized in the current analysis, subjective norm has been found to exert no influence on the perceptions of usefulness $\left(\mathrm{H}_{5}\right)$. This finding is not in harmony with Venkatesh and Davis (2000), who have empirically confirmed that the social aspect of subjective norm has a positive and direct influence on perceived usefulness in the adoption-related research studies. In the meantime, on critically reviewing the literature on the role of subjective norm in the adoption of different IT domains and different cultural settings, it is clear that the subjective norm construct has had inconclusive and mixed results. More, the current results reveal that the social aspect of subjective norm has a significantly direct and positive correlation with perceived image $\left(\mathrm{H}_{6}\right)$. Meanwhile, the current findings point to that image construct directly influences perceived usefulness $\left(\mathrm{H}_{7}\right)$. The outcome of this study evidently reveals that image is important to individuals in gaining status and reputation from using m-payment technology. Indeed, these results are consistent with previous findings (Venkatesh \& Davis, 2000; Venkatesh \& Bala, 2008). It is true, however, that the subjective norm has indirect influence on perceived usefulness through the social aspect of perceived image $\left(\mathrm{H}_{6}\right.$ and $\left.\mathrm{H}_{7}\right)$. Certainly, if customers find mobile environment useful tools for settling financial transactions and can improve their social image and status they will be eager to adopt it. More, the current analysis reveals that the social aspect of image does not influence the behavioral intention to use m-payment system in Jordan $\left(\mathrm{H}_{8}\right)$. This result is inconsistent with the conclusions provided by Njuguna et al. (2012) in the domain of Internet banking technology.

The output quality aspect can capture the influence of cognitive instrumental processes on the perceptions of usefulness (Venkatesh \& Davis, 2000). The output quality can also be seen as the degree to which one thinks that a new innovation can perform required tasks. The current empirical findings confirm that the output quality is a prominent determinant which influences both the perceived usefulness and behavioral intentions of m-payment adoption $\left(\mathrm{H}_{9}\right.$ and $\left.\mathrm{H}_{10}\right)$. Similar findings can be found in literature regarding the positive influence of output quality on perceived usefulness (Venkatesh \& Davis, 2000; Venkatesh \& Bala, 2008; Pai\& Huang, 2011). However, to our knowledge, there are no similar studies in IT literature that conceptualizes the relationship between output quality and intention, particularly with respect to the domain of m-payment technology, therefore comparison of findings is very much difficult to make. In conclusion, this indicates that if customers are contended with the quality of m-payment systems they are likely to perceive it as useful. As a result, m-payment must be able to provide sufficient output quality to the users that influence their perceptions of its quality and enhances their levels of satisfaction. Therefore, this will increase the possibility for the rate of adoption of m-payment to go faster.

As mentioned earlier, result demonstrability is about the extent to which certain attributes of the system can be measured. Contrary to what has been hypothesized in the current research study $\left(\mathrm{H}_{11}\right)$, the outcome of this study does not empirically establish the statistical influence of result demonstrability construct on perceived usefulness. This result is not in harmony with conclusions provided by Venkatesh and Davis (2000) and Venkatesh and Bala (2008). However, revisiting the literature, one can clearly find that the role of result demonstrability on determining the perceptions of usefulness in technology acceptance of various information technology systems has been mixed. For example, Moore and Benbasat (1991) stated that result demonstrability aspect is an important concept for capturing individual's perception on innovation's tangible results of using the innovation. However, Chong and Chan (2012) concluded that result demonstrability had no influence on the users' perceptions of usefulness. Besides, in the light of the findings of the current study, result demonstrability aspect has been found to have a positive correlation with behavioral intentions to use m-payment $\left(\mathrm{H}_{12}\right)$. Similar finding with respect to Internet banking technology adoption was revealed by Njuguna et al. (2012). The current study suggests that the influence of the result demonstrability aspect on the adoption of a new innovation is heavily based upon whether the characteristics of the innovation are able to demonstrate any potential benefits to the users or not. As a result, m-payment technology developers and providers should improve the quality of the m-payment system process in order to generate greater positive consumers' perceptions of the usefulness of the 
system.

One of the main objectives of this study is to investigate the possible moderating effects of gender and self-efficacy constructs on m-payment adoption in Jordan. This study has tested the moderating effect of gender on all the relationships hypothesized in the model of this study (with the exception of the relationship between subjective norm and image). This study demonstrates that gender differences have not established any influence as a moderator among all the relationships tested in the current model. More clearly, the statistical analysis of this study has empirically demonstrated that gender differences do not have any significant influence on the adoption of m-payment channel. Therefore, the current findings suggest that gender dimension does not lead to any difference in individuals' intentional behavior towards adoption of m-payment technology in Jordan. These results are inline with prior research studies. For example, similar conclusions were drawn by Hamza and Shah (2014) who revealed that gender differences exert no moderating effects on the adoption process of m-payment technology among university students in a developing country context of Nigeria, particularly among the primary TAM-related relationships. Also, Li et al. (2014) have proposed a model to investigate factors that influencing the intention of m-payment system in China, they have concluded that different genders have exhibited similar perceptions and orientations towards willingness to adopt m-payment technology. Further, many other studies have provided conclusions that gender differences have been found to have little moderating influence in various IT adoption contexts (Bigne et al., 2005; Zhou et al., 2007; Calisir et al., 2009; Lip-Sam \& Hock-Eam, 2011). Finally, the current study has concluded that different genders pursue the same pattern of perception development in formation of behavioral outcomes in relation to m-payment adoption process. Overall, based on the findings of this study, it is confirmed that gender has a very limited moderating effects on $\mathrm{m}$-payment context in Jordan. The current result believes that with respect to m-payment context, undergraduate students of both genders are heavy users of mobiles to get ubiquitous access to the Internet and social media. As a result, it seems that the gender gap in mobile-based applications such as m-payment has significantly shrunk in Jordan.

Also, the present study is set out to investigate the moderating role of self-efficacy in the context of m-payment behavior through the lens of TAM2 in a developing country context of Jordan. In reality, this type of analysis is surprisingly absent from IT literature, therefore lack of such analysis has mobilized the launch of the current work. Therefore, this study is the first attempt to hypothesize the relationships among constructs in TAM2 model to be moderated by mobile self-efficacy. The current findings report that only three relationships out of eight suggested are moderated by self-efficacy aspect $\left(\mathrm{H}_{24}, \mathrm{H}_{26}\right.$, and $\left.\mathrm{H}_{27}\right)$. The current findings have established that the moderation role of self-efficacy on the relationship between output quality and perceived usefulness is negative $\left(\mathrm{H}_{24}\right)$, implying that the higher the self-efficacy the lesser influence of output quality on the perceptions of usefulness. Indeed, once consumers are able to translate knowledge, skills and essential behaviors they acquire into actionable implementation intentions, or in another words having higher levels of self-efficacy, thus the influence of output quality on the perceptions of usefulness will be weaker. This means that consumers with high self-efficacy do not consider output quality an important aspect in improving their own perceptions of usefulness (see Figure 4). Similarly, in the case of the relationship between perceived ease of use and perceived usefulness, the moderation effect of self-efficacy is negative. Therefore, the higher self-efficacy the lesser influence of perceived ease of use on perceived usefulness. This implies that high self-efficacy dampens the intensity of relationship between perceived ease of use and perceived usefulness (see Figure 5). 

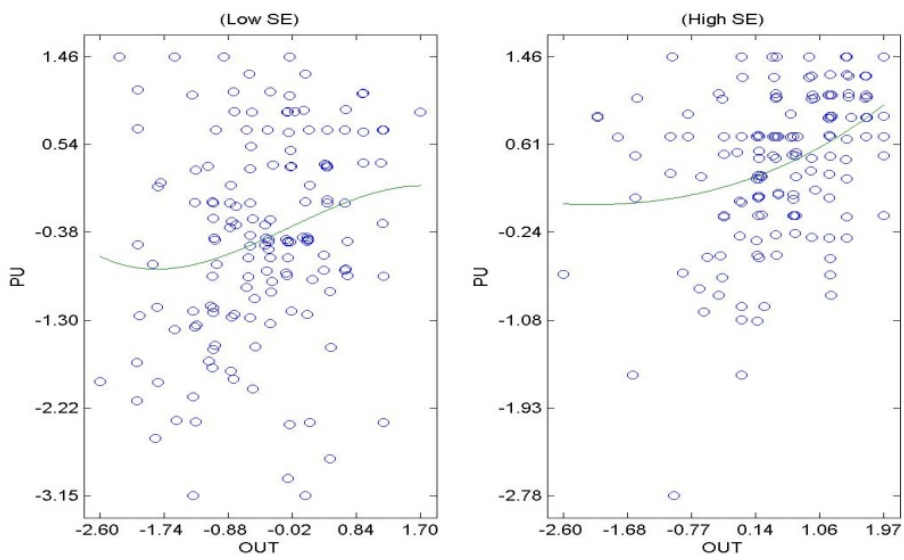

Figure 4. Moderation effect of self-efficacy on the relationship between perceived usefulness and output quality
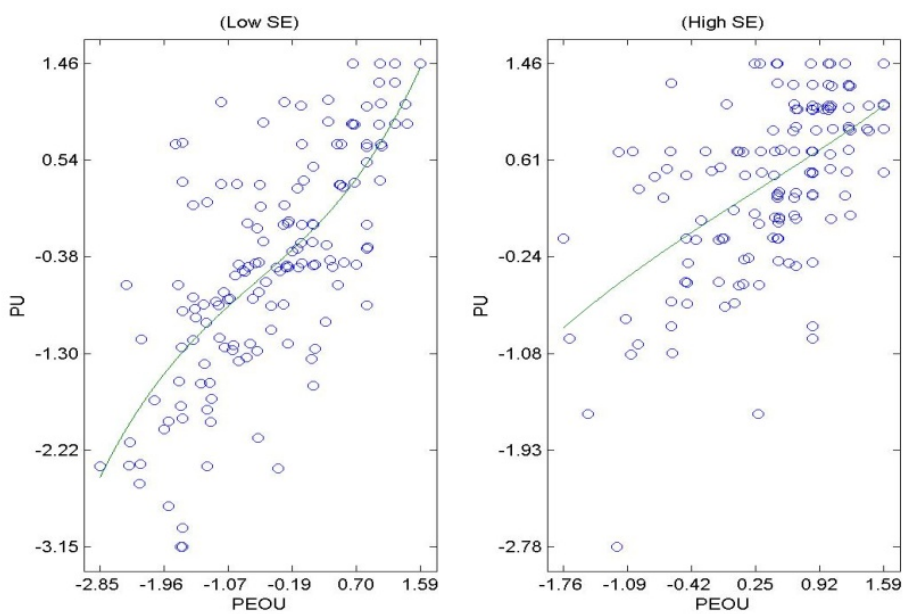

Figure 5. Moderation effect of self-efficacy on the relationship between perceived usefulness and perceived ease of use

Effectively, as a result, consumers with higher degree of self-efficacy feel in control and more comfortable using the technology and have the tendency to be perceptually positive towards adoption of the technology. However, the relationship between perceived usefulness and behavioral intention has been found to be positively moderated by the self-efficacy aspect (see Figure 6). 

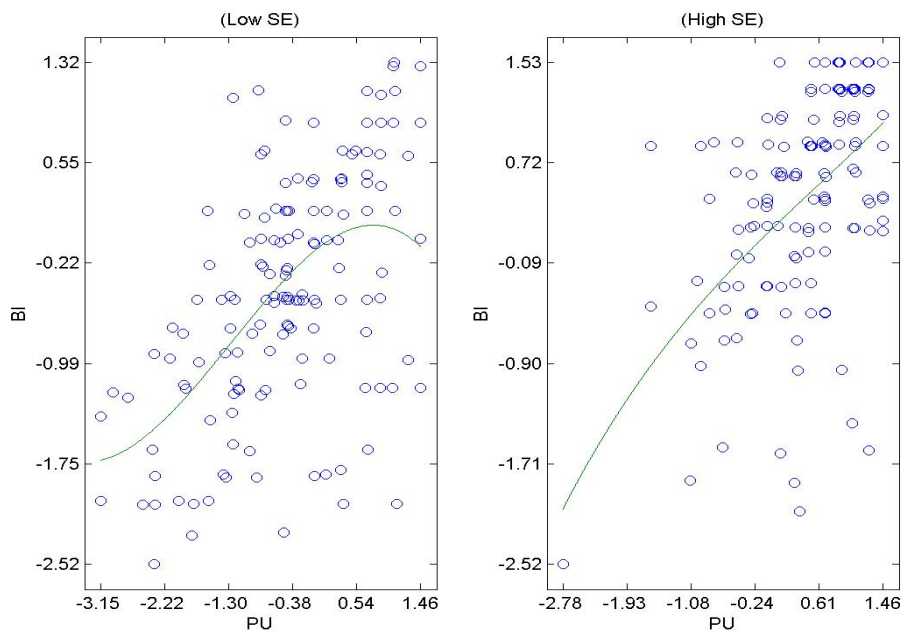

Figure 6. Moderation effect of self-efficacy on the relationship between behavioral intention and perceived usefulness

A similar conclusion was reported in mobile commerce adoption domain by Islam et al. (2011). In fact, this result indicated that the higher self-efficacy the greater effect of perceived usefulness on behavioral intention. Indeed, the result of this study is very interesting because having higher self-efficacy helps translate the consumers' perceptions of usefulness into behavioral intention leading to actual use of the technology. Further, self-efficacy was statistically found to have little moderation effect on the relationships between subjective norm, image, and result demonstrability constructs with perceived usefulness. This implies that variation in self-efficacy among users will not influence the impact of these constructs (subjective norm, image, and result demonstrability) on the perceptions of usefulness.

\subsection{Theoretical Contributions}

This research serves to offer valuable contributions to existing literature. First, this study has contributed to theoretically better understand the dynamics of m-payment technology adoption by consumers of a developing country context of Jordan. Second, the current study is based on TAM2 theoretical framework, whereby its boundary has been extended with two moderating factors: gender and self-efficacy. However, the moderating role of gender and self-efficacy often tends to be overlooked in the investigation into adoption of mobile business technologies, especially in relation to Arab culture. As a result, this empirical study contributes largely to the existing knowledge base by filling the current literature gap concerning the moderating effects of consumer gender and self-efficacy in the adoption of m-payment in context of a developing country of Jordan. Third, the current findings demonstrate that both perceived usefulness and perceived ease-of-use beliefs are primarily important in m-payment adoption process. This study reinforces the importance of these beliefs in the adoption of m-payment domain in a developing country context through the lens of TAM2. Indeed, this is an important contribution by itself because these types of conclusions, given the domain and the context of this study, are unexpectedly missing from literature. Fourth, the current findings indicate that TAM2 totally explains the intention to use m-payment since the reported average variance explained (AVE) in all variables is above the threshold value of 0.5 . Also, the results indicate that the Cronbach alpha and composite reliability for all variables are above 0.6 and 0.7 , respectively. These results demonstrate the theoretical validity and the empirical applicability of TAM 2 model in a developing country context in which culture and values are largely different from western world and in a domain of mobile-based technology such as m-payment. We believe that this is a significant theoretical contribution emerging from this study. Fifth, the current study shows that gender differences have no moderating effects on the adoption of m-payment process in the Jordanian context. This is a vital contribution because it suggests that gender gap appears to have largely narrowed in a developing countries context. These findings imply that different genders follow the same pattern of perception development in formation of behavioral outcomes in relation to m-payment adoption. Sixth, this study concludes that Jordanians are exposed to social influences when making decisions to adopt and use mobile technology for payment. Finally, another scholarly contribution of importance is that self-efficacy as a moderator has a significant influence on the adoption process of m-payment technology. In the light of the current findings, the moderation influence of 
self-efficacy can impact largely the adoption process of m-payment in a way that it may positively facilitate and immeasurably accelerate the rate of its adoption. The importance of this contribution is attributed to the fact that the moderation influence of self-efficacy has never been addressed in literature in relation to mobile-based technologies such as m-payment. Indeed, this adds to the body of IT knowledge new insights and perspectives that could prove substantially sound if translated to actual practical implementations and strategies.

\subsection{Practical Implementations}

The current study provides some useful practical implementations. First, the user perceptions of usefulness and ease-of- use of the technology are vitally important constructs regarding the adoption of m-payment since these beliefs positively influence users' behavioral intentions towards the technology. Therefore, improving the adoption pace of acceptance and adoption of the technology can be achieved through enhancements of perceptions of usefulness and ease-of- use of m-payment. Users must perceive that m-payment process augments their job performance and is easy to use. It is commonly understood that mobile technology has its own limitations in terms of features, designs, usage, and implementation. Thus, it is highly challenging for development practitioners and developers to design systems that offer mobile environment with highly usable features. Therefore, delivering an appropriate and effective interface design for mobile devices plays a critical role in the successful adoption of m-payment channel. Definitely, it is imperative to investigate how to better develop and design innovative m-payment systems capable of facilitating efficient and convenient financial transactions.

Second, this study has primarily focused on revealing the crucial determinants of perceived usefulness. The current findings reveal that image and output quality determinants are empirically important for the perceptions of usefulness of m-payment adoption. This implies that users' perception towards m-payment adoption is heavily dependent on how much the adoption of a technological innovation can enhance their social status and prestige. Therefore, marketers must associate the adoption decisions with gaining social status to promote the adoption of m-payment channel. This study also concludes that output quality is a prominent determinant of perceived usefulness to use mobile payment technology. Also, many authors have established that potential adopters would be inclined to choose a system that delivers the highest output quality (Venkatesh \& Davis, 2000, Venkatesh \& Bala, 2008; Pai \& Huang, 2011. Furthermore, the current findings conclude that output quality determinant has a positive influence on behavioral intention to adopt and use m-payment. Therefore, any method can enhance the quality of the output and can provide more important leverage for increasing individuals' adoption is essential for developers to implement (Pai \& Huang, 2011). Therefore, it is fundamental for developers to establish and design practical interventions in order to modify positively users' behavior towards adoption and usage of m-payment technology by means of achieving an improvement in the individual's perception that the system provides sufficient output quality. In conclusion, developers of m-payment applications must pursue means of exploiting these insights to promote the perceptions of usefulness of the technology.

Third, the effect of subjective norm on intention concluded by the current study demonstrates that m-payment adoption can be enhanced and improved by motivating consumers' perceptions through families and social circles, and also advertisements can be utilized to generate an encouraging environment that stimulates users' perceptions positively towards adoption of m-payment technology. Fourth, the current findings have empirically revealed that gender differences have no impact on the adoption process of m-payment technology in Jordan. Speaking in business language, m-payment technology is not a gendered phenomenon with respect to the context of Jordan which indicates that this technology resonates equally with both genders, and therefore there is no need to segment population based on gender and accordingly both genders can be targeted using the same marketing strategies. Finally, the findings provided by this study demonstrate that the aspect of self-efficacy has a significant moderation influence on m-payment adoption process. Admittedly, the moderation role of self-efficacy in domains of consumer behavior has been little researched, particularly in the contexts of virtual environments. However, it is a challenging task for developers and marketers to be able to develop methods and ways to improve one's self-efficacy in order to improve the likelihood of consumers' capacity to adopt and use the technology of m-payment. Indeed, self-efficacy expectations are learned and improvement can be made through education, training and performance accomplishments in order to dampen the influence of anxiety and phobia associated with using technologies like m-payment (Bandura, 1997).

\subsection{Conclusions}

This study proposed a theoretical model based on TAM2 to investigate m-payment adoption in a developing country of Jordan. The study offers the following conclusions. First, perceived usefulness, perceived ease of use, subjective norm, output quality, and result demonstrability constructs have significant influence on behavioral 
intention to use m-payment technology, whereas perceived usefulness was found to exert the strongest influence on intention to use m-payment technology. Second, the perceived ease of use variable has strong influence on perceived usefulness of the technology with a path coefficient of 0.641 . Third, the subjective norm influences indirectly the perceptions of usefulness through the social aspect of image. Fourth, both output quality and image determinants influence the perceptions of usefulness. Fifth, the gender differences have no significant statistical moderation on m-payment technology adoption in Jordan. Finally, self-efficacy has some moderation role of importance to play on the process of m-payment adoption.

\subsection{Limitations and Future Studies}

In closing, this study has its limitations. First, the choice of student subjects can limit the generalization of findings because of the possible unique characteristics of this demographic. Future studies should broaden the scope of the sample frame beyond a convenience sample of university students to make it more representative of general population. Second, this study has drawn upon existing measurement scales and items that have been tested and validated in previous studies. However, applying these scales and items to a different research setting may be fraught with uncertainties. Therefore, future studies should determine a suitable measurement scales that practically suit the peculiarity of Jordan environment and cultural setting. Because replicating this study using different measurement items would contribute to verification of the proposed model. Third, variables (such as trust, perceived risk, security and privacy) and moderators (such as cultural issues and socio-economic characteristics like income, age, and education) could be incorporated in future studies to increase our understanding of the dynamics of m-payment. Finally, future research studies should adopt a longitudinal study approach to provide valuable insights regarding the individuals' perceptions and usage of m-payment technology in order to further understand more deeply the dynamics of this innovative technology.

\section{References}

Advanced Payments $\quad$ Report. $\quad$ (2014). $\quad$ Retrieved from http://www.paymentscardsandmobile.com/wp-content/uploads/2014/02/PCM_EDC_Advanced_Payments_ Report_2014_MWC.pdf

Ahuja, M. K., Chudoba, K. M., Kacmar, C. J., McKnight, D. H., \& George, J. F. (2007). IT road warriors: Balancing work-family conflict, job autonomy, and work overload to mitigate turnover intentions. MIS Quarterly, 31(1), 1-17.

Alessandri, G., Borgogni, L., Schaufeli, W. B., Caprara, G. V., \& Consiglio, C. (2014). From Positive Orientation to Job performance: The Role of Work Engagement and Self-efficacy Beliefs. Journal of Happiness Studies, 1-22. http://dx.doi.org/10.1007/s10902-014-9543-2.

Amin, H. (2007). Internet Banking Adoption among Young Intellectuals. Journal of Internet Banking and Commerce, 12(3), 1-13.

Arab Advisers Group. (2013). Retrieved from http://www.arabadvisors.com/Pressers/presser-230713.htm

Au, N., Ngai, E., \& Cheng, T. (2008). Extending the understanding of end user information systems satisfaction formation: An equitable needs fulfillment model approach. MIS Quarterly, 32(1), 43-66.

Bandura, A. (1997). Self-efficacy and health behaviour. In A. Baum, S. Newman, J. Wienman, R. West, \& C. McManus (Eds.), Cambridge handbook of psychology, health and medicine (pp. 160-162). Cambridge: Cambridge University Press.

Bao, Y., Xiong, T., Hu, Z., \& Kibelloh, M. (2013). Exploring Gender Differences on General and Specific Computer Self-Efficacy in Mobile Learning Adoption. Journal of Educational Computing Research, 49(1), 111-132. http://dx.doi.org/10.2190/EC.49.1.e

Bigne, E., Ruiz, C., \& Sanz, S. (2005). The impact of internet user shopping patterns and demographics on consumer mobile buying behaviour. Journal of Electronic Commerce Research, 6(3), 193-209.

Bouwman et al. (2012). Consumer lifestyles: alternative adoption patterns for advanced mobile services. International Journal of Mobile Communications (IJMC), 10(2), 169-189. http://dx.doi.org/10.1504/IJMC.2012.045672

Calisir, F., Gumussoy, C. A., \& Bayram, A. (2009). Predicting the Behavioral Intention to Use Enterprise Resource Planning Systems: an Exploratory Extension of the Technology acceptance model. Manage. Res. News, 32(7), 597-613. http://dx.doi.org/10.1108/01409170910965215

Campbell, D. T. (1960). Recommendations for APA test standards regarding construct, trait, or discriminant 
validity. The American Psychologist, 15, 546-553. http://dx.doi.org/10.1037/h0048255

Cenfetelli, R., \& Bassellier, G. (2009). Interpretation of formative measurement in information systems research. MIS Quarterly, 33(4), 689-708.

Centre for Economics and Business Research. (2014). Retrieved from http://Mobile-payment-benefits-to-retailers-and-consumers-Cebr-Zapp-report-FINAL-19.03.2014.pdf

Chan, S. C., \& Lu, M. T. (2004). Understanding Internet Banking Adoption and Use behaviour: A Hong Kong perspective. Journal of Global Information Management, 12(3), 12-43. http://dx.doi.org/10.4018/jgim.2004070102

Chang, M. K., Cheung, W., \& Lai, V. S. (2005). Literature derived reference models for the adoption of online shopping. Information and Management, 42(4), 543-559. http://dx.doi.org/10.1016/j.im.2004.02.006

Chin, W. W., Marcolin, B. L., \& Newsted, P. R. (2003). A Partial Least Squares Latent Variable Modeling Approach for Measuring Interaction Effects: Results from a Monte Carlo Simulation Study and an Electronic-Mail Emotion/Adoption Study. Information Systems Research, 14(2), 189-217. http://dx.doi.org/10.1287/isre.14.2.189.16018

Chong, A. Y. L., \& Chan, F. T. S. (2012). Understanding the Acceptance of RFID in the Healthcare Industry: Extending the TAM Model. Decision-Making for Supply Chain Integration, 1, 105-122. http://dx.doi.org/10.1007/978-1-4471-4033-7_6

Chuttur, M. Y. (2009). Overview of the Technology Acceptance Model: Origins, Developments and Future Directions, Indiana University. Working Papers on Information Systems, 9(37).

Compeau, D. R., \& Higgins, C. A. (1995). Computer Self-Efficacy: Development of a Measure and Initial Test. MIS Quarterly, 19(2), 189-211. http://dx.doi.org/10.2307/249688

Cyr, D., \& Bonanni, C. (2005). Gender and website design in e-business. International Journal of Electronic Business, 3(6), 565-582. http://dx.doi.org/10.1504/IJEB.2005.008536

Dahlberg, T., Mallat, N., Ondrus, J., \& Zmijewska, A. (2008). Past, present and future of mobile payments research: a literature review. Electronic Commerce Research and Applications, 7(2), 165-181. http://dx.doi.org/10.1016/j.elerap.2007.02.001

Davis, F. (1989). Perceived usefulness, perceived ease of use, and User Acceptance of Information Technology. MIS Quarterly, 13(3), 318-339. http://dx.doi.org/10.2307/249008

Davis, F. D., Bagozzi, R. P., \& Warshaw, P. R. (1989). User acceptance of computer technology: a comparison of two theoretical models. Manage. Sci., 35(8), 982-1003.

Dong, J. Q., \& Zhang, X. (2011). Gender differences in adoption of information systems: New findings from China. Computers in Human Behavior, 27(1), 384-390.

Eze, U. C., Goh, M. H., Ling, H. Y., \& Lee, C. H. (2011). Intention to Use E-Government Services in Malaysia: Perspective of Individual Users. Informatics Engineering and Information Science, 512-526. http://dx.doi.org/10.1007/978-3-642-25453-6_43

Faqih, K. (2013). Exploring the Influence of Perceived Risk and Internet Self-efficacy on Consumer Online Shopping Intentions: Perspective of Technology Acceptance Model. International Management Review, 9(1), 69-78.

Faqih, K. M. S. (2011). Integrating perceived risk and trust with technology acceptance model: An empirical assessment of customers' acceptance of online shopping in Jordan. In 2011 International Conference on Research and Innovation in Information Systems (ICRIIS), 1-5. http://dx.doi.org/10.1109/ICRIIS.2011.6125686

Fishbein, M., \& Ajzen, I. (1975). Belief, Attitude, Intentions and Behavior: An Introduction to Theory and Research. Boston: Addison-Wesley. http://dx.doi.org/10.1109/ICRIIS.2011.6125686

Fornell, C., \& Larcker, F. L. (1981). Evaluating Structural Equation Models with Unobservable Variables and Measurement Error. Journal of Marketing Research, 18, 39-50. http://dx.doi.org/10.2307/3151312

Forrester. (2013). Retrieved from http://blogs.forrester.com/denee_carrington/13-01-16-us_mobile_payments_forecast_2013_2017_mobile_p ayments_to_reach_90b_by_2017

Gartner. (2012). Retrieved from http://www.gartner.com/newsroom/id/2028315 
Gefen, D., \& Straub, D. W. (1997). Gender difference in the perception and use of e-mail: An extension to the technology acceptance model. MIS Quarterly, 21(4), 389-401. http://dx.doi.org/10.2307/249720

Goffee, R., \& Jones, G. (1996). What holds the modern company together? Harvard Business Review, 74, $133-148$.

Goh, T. T. (2011). Exploring Gender Differences in SMS-Based Mobile Library Search System Adoption. Journal of Educational Technology \& Society, 14(4).

Grau, R., Salanova, M., \& Peiró, J. M. (2001). Moderator effects of self-efficacy on occupational stress. Psychology in Spain, 5(1), 63-74.

GSMA Intelligence. (2014). Retrieved from https://gsmaintelligence.com/files/analysis/?file=2014-05-22-measuring- mobile-penetration.pdf

Gu, J., Lee, S., \& Suh, Y. (2009). Determinants of behavioral intention to mobile banking. Expert Systems with Applications, 36(9), 11605-11616. http://dx.doi.org/10.1016/j.eswa.2009.03.024

Hair, J. F., Black, W. C., Babin, B. J., \& Anderson, R. E. (2009). Multivariate data analysis. Upper Saddle River, NJ: Prentice Hall.

Hair, J., Babin, B., Money, A., \& Samouel, P. (2003). Essentials of Business Research Methods. New York: John Wiley \& Sons Inc.

Hamza, A., \& Shah, A. (2014). Gender and Mobile Payment System Adoption among Students of Tertiary Institutions in Nigeria. International Journal of Computer and Information Technology, 3(1).

Hasan, B. (2010). Exploring gender differences in online shopping attitude. Computers in Human Behavior 26(4), 597-601. http://dx.doi.org/10.1016/j.chb.2009.12.012

Hayashi, F. (2012). Mobile payments: What's in it for consumers? Economic Review, (QI), 35-66.

$\mathrm{Hu}, \mathrm{X} ., \mathrm{Li}, \mathrm{W} .$, \& Hu, Q. (2008). Are mobile payment and banking the killer apps for mobile commerce? In Proceedings of the 41st Hawaii international conference on system sciences, 7-10 January, Waikoloa, Big Island, HI, USA. Washington. http://dx.doi.org/10.1109/HICSS.2008.69

Hussey, J., \& Hussey, R. (1997). Business Research: A Practical Guide for Undergraduate and Postgraduate Students. Macmillan, London.

Iconaru, C. (2013). The Moderating Role of Perceived Self-efficacy in the Context of Online Buying Adoption. BRAND. Broad Research in Accounting, Negotiation, and Distribution, 4(1), 20.

International Telecommunication Union (ITU). (2014). Retrieved from http://mobithinking.com/mobile-marketing-tools/latest-mobile-stats/a

Islam, M., Khan, M. A., Ramayah, T., \& Hossain, M. M. (2011). The Adoption of Mobile Commerce Service among Employed Mobile Phone Users in Bangladesh: Self-efficacy as A Moderator. International Business Research, 4(2). http://dx.doi.org/10.5539/ibr.v4n2p80

Jaradat, M. I., \& Al-Mashaqba, A. (2014). Understanding the adoption and usage of mobile payment services by using TAM3. Int. J. Business Information Systems, 16(3), 271-296. http://dx.doi.org/10.1504/IJBIS.2014.063768

Jayawardhena, C., Kuckertz, A., Karjaluoto, H., \& Kautonen, T. (2009). Antecedents to permission based mobile marketing: an initial examination. European Journal of Marketing, 43(3/4), 473-499. http://dx.doi.org/10.1108/03090560910935541

The Jordan Times. (2014a). from http://jordantimes.com/95-of-jordanians-own-mobiles-47-use-the-internet

$\begin{array}{cccc}\text { The Jordan } & \text { Times. } & \text { (2014b). } & \text { Retrieved }\end{array}$ http://jordantimes.com/zain-jordan--to-introduce-4g-services-by-year-end

Khraim, H. S., Shoubaki, Y. E., \& Khraim, A. S. (2011). Factors affecting Jordanian consumers' adoption of mobile banking services. International Journal of Business and Social Science, 2(20), 96-105.

Kim, C., Mirusmonov, M., \& Lee, I. (2010). An empirical examination of factors influencing the intention to use mobile payment. Computers in Human Behavior, 26(3), 310-322. http://dx.doi.org/10.1016/j.chb.2009.10.013

Kock, N. (2013). WarpPLS 4.0 User Manual, Script Warp Systems, Laredo Texas. Retrieved from 
http://www.scriptwarp.com/warppls/UserManual.pdf

Kock, N. (2011). WarpPLS 2.0. User Manual. Laredo, Texas: Script Warp Systems.

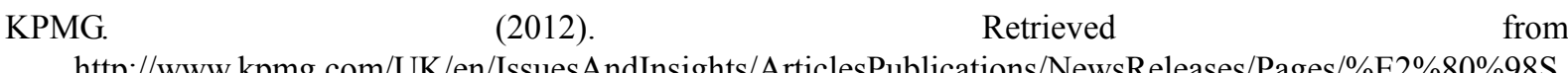
mart-phone-and-tablet-popularity-brings-maturity-to-mobile-payment-marketplace $\% \mathrm{E} 2 \% 80 \% 99$-says-KPM G.aspx

Li, C., \& Zhang, M. (2012). Research on the Factors Affecting Consumers' Willingness to the Use of Mobile Payment. Advances in Computer Science and Engineering, 575-580. Springer Berlin Heidelberg.

Li, J., \& Liu, J. L., \& Yong, J, H. (2014). Empirical Study of Influence Factors of Adaption Intention of M-payment based on TAM Model in China. International Journal of $u$ - and e-Service, Science and Technology, 7(1), 119-132.

Lichtenstein, S., \& Williamson, K. (2006). Understanding Consumer Adoption of Internet Banking: An Interpretive Study in the Australian Banking Context. Journal of Electronic Commerce Research, 7(2), 50-66.

Liébana-Cabanillas, F., Sánchez-Fernández, J., \& Muñoz-Leiva, F. (2014). Antecedents of the adoption of the new mobile payment systems: The moderating effect of age. Computers in Human Behavior, 35, 464-478. http://dx.doi.org/10.1016/j.chb.2014.03.022

Limayem, M., Hirt, S. G., \& Cheung, C. M. K. (2007). How habit limits the predictive power of intention: The case of information systems continuance. MIS Quarterly, 31(4), 705-737.

Linck, K., Pousttchi, K., \& Wiedemann, D. G. (2006). Security issues in mobile payment from the customer viewpoint. In Proceedings of the 14th European Conference on Information Systems (ECIS 2006), Göteborg.

Lip-Sam, T., \& Hock-Eam, L. (2011). Estimating the determinants of B2B e-commerce adoption among small \& medium enterprises. International Journal of Business and Society, 12(1), 15-30. Retrieved from http://www.ijbs.unimas.my/most-popular/ item/download/ 19 _69720a3c7f5abff5f34f2f73793148d2.html

Loch, K. D., Straub, D. W., \& Kamel, S. (2003). Diffusing the internet in the Arab world: The role of social norms and technological culturation. IEEE Transactions on Engineering Management, 50(1), $45-63$. http://dx.doi.org/10.1109/TEM.2002.808257

Lu, J., Liu, C., Yu, C. S., \& Wang, K. (2008). Determinants of accepting wireless mobile data services in China. Information \& Management, 45, 52-64. http://dx.doi.org/10.1016/j.im.2007.11.002

Lu, J., Yu, C. S., Liu, C., \& Yao, J. E. (2003). Technology acceptance model for wireless internet. Internet Research, 13(3), 206-222. http://dx.doi.org/10.1108/10662240310478222

Lu, X., \& Viehland, D. (2008). Factors Influencing the Adoption of Mobile Learning. ACIS 2008 Proceedings. Paper 56. Retrieved from http://aisel.aisnet.org/acis2008/56

Lu, Y., Yang, S., Chau, P. Y., \& Cao, Y. (2011). Dynamics between the trust transfer process and intention to use mobile payment services: A cross-environment perspective. Information \& Management, 48(8), $393-403$. http://dx.doi.org/10.1016/j.im.2011.09.006

Mallat, N. (2007). Exploring consumer adoption of mobile payments - A qualitative study. Journal of Strategic Information Systems, 16, 413-432. http://dx.doi.org/10.1016/j.jsis.2007.08.001

Marchewka, J. T., Liu, C., \& Kostiwa, K. (2007). An Application of the UTAUT Model for Understanding Student Perceptions Using Course Management Software. Communications of the IIMA, 7(2), 93-104.

Moore, G. C., \& Benbasat, I. (1991). Development of an instrument to measure the perceptions of adopting an information technology innovation. Information Systems Research, 2(3), $192-222$. http://dx.doi.org/10.1287/isre.2.3.192

Njuguna, P. K., Ritho, C., Olweny, T., \& Wanderi, M. P. (2012). Internet Banking Adoption in Kenya: The Case of Nairobi County. International Journal of Business and Social Science, 3(18), 246-252.

Ondrus, J., \& Pigneur, Y. (2006). Towards a holistic analysis of mobile payments: A multiple perspectives approach. Electronic Commerce Research and Applications, 5(3), 246-257. http://dx.doi.org/10.1016/j.elerap.2005.09.003

Ong, C. S., \& Lai, J. Y. (2006). Gender differences in perceptions and relationships among dominants of 
e-learning acceptance. Computers in Human Behavior, 22(5), 816-829. http://dx.doi.org/10.1016/j.chb.2004.03.006

Ong, J. W., Poong, Y. S., \& Ng, T. H. (2008). 3G services adoption among university students: Diffusion of innovation theory. Communications of the IBIMA, 3(16), 114-121.

Pai, F. Y., \& Huang, K. I. (2011). Applying the Technology Acceptance Model to the introduction of healthcare information systems. Technological Forecasting and Social Change, 78(4), 650-660. http://dx.doi.org/10.1016/j.techfore.2010.11.007

Pavlou, P. A., \& Fygenson, M. (2006). Understanding and prediction electronic commerce adoption: An extension of the theory of planned behavior. MIS Quarterly, 30(1), 115-143.

Pavlou, P. A., \& Sawy, O. A. E. (2006). From IT leveraging competence to competitive advantage in turbulent environments: The case of new product development. Information Systems Research, 17(3), 198-227. http://dx.doi.org/10.1287/isre.1060.0094

Petter, S., Straub, D. W., \& Rai, A. (2007). Specifying formative constructs in information systems research. MIS Quarterly, 31, 623-656.

Pousttchi, K., \& Wiedemann, D. G. (2007). What Influences Consumers'Intention to Use Mobile Payments. LA Global Mobility Round table.

Riquelme, H. E., \& Rios, R. E. (2010). The moderating effect of gender in the adoption of mobile banking. International Journal of Bank Marketing, 28(5), 328-341. http://dx.doi.org/10.1108/02652321011064872

Sadi, S., \& Noordin, M. F. (2011). Developing and validating an instrument for measuring M-commerce adoption: an exploratory analysis. International Journal of Network and Mobile Technologies, 3(1), 39-47.

Schierz, P. G., Schilke, O., \& Wirtz, B. W. (2010). Understanding consumer acceptance of mobile payment services: An empirical analysis. Electronic Commerce Research and Applications, 9(3), $209-216$. http://dx.doi.org/10.1016/j.elerap.2009.07.005

Schreurs, B., Van Emmerik, H., Notelaers, G., \& De Witte, H. (2010). Job insecurity and employee health: The buffering potential of job control and job self-efficacy. Work \& Stress, 24(1), 56-72. http://dx.doi.org/10.1080/02678371003718733

Sekaran, U. (2006). Research Methods for Business a Skill-Building Approach (4th ed.). New Delhi, John Wiley and Sons.

Shin, D. H. (2007). User acceptance of mobile Internet: Implication for convergence technologies. Interacting with Computers, 19(4), 472-483. http://dx.doi.org/10.1016/j.intcom.2007.04.001

Shin, D.H. (2009). Towards an understanding of the consumer acceptance of mobile wallet. Computers in Human Behavior, (25), 1343-1354. http://dx.doi.org/10.1016/j.chb.2009.06.001

Sim, J. J., Kong, F. M., Lee, V. H., Tan, G. W. H., \& Teo, A. C. (2012). Determining factors affecting broadband services adoption: an empirical analysis of Malaysian consumers. International Journal of Services, Economics and Management, 4(3), 236-251. http://dx.doi.org/10.1504/IJSEM.2012.048621

Simosi, M. (2012). The moderating role of self-efficacy in the organizational culture-training transfer relationship. International Journal of Training and Development, 16(2), 92-106. http://dx.doi.org/10.1111/j.1468-2419.2011.00396.x

Suls, J., \& Wallston, K. A. (Eds.). (2008). Social psychological foundations of health and illness. John Wiley \& Sons. http://dx.doi.org/10.1002/9780470753552

Sun, H., \& Zhang, P. (2006). The role of moderating factors in user technology acceptance. International Journal of Human-Computer Studies, 64(2), 53-78. http://dx.doi.org/10.1016/j.ijhcs.2005.04.013

Sun, Y., Wang, N., Guo, X., \& Peng, Z. (2013). Understanding the Acceptance of Mobile Health Services: A Comparison and Integration of Alternative Models. Journal of Electronic Commerce Research, 14(2), 183-200.

Tan, G. W. H., Ooi, K. B., Chong, S. C., \& Hew, T. S. (2014). NFC mobile credit card: the next frontier of mobile payment? Telematics and Informatics, 31(2), 292-307. http://dx.doi.org/10.1016/j.tele.2013.06.002

Teo, T. S. H., \& Pok, S. H. (2003). Adoption of WAP-Enabled Mobile Phones among Internet Users. Omega, 31(6), 483-498. http://dx.doi.org/10.1016/j.omega.2003.08.005 
Terzis, V., \& Economides, A. A. (2011). Computer based assessment: Gender differences in perceptions and acceptance. Computers in Human Behavior, 27(6), 2108-2122. http://dx.doi.org/10.1016/j.chb.2011.06.005

Ultimate Middle Ease Business Resource. (2014). Retrieved from http://www.ameinfo.com/blog/telecoms/mobile-payment-to-start-in-jordan-as-of-march/

Van Slyke, C., Lou, H., Belanger, F., \& Sridhar, V. (2010). The influence of culture on consumer-oriented electronic commerce adoption. Journal of Electronic Commerce Research, 11(1), 30-40.

Venkatesh, V., \& Davis, F. D. (2000). A theoretical extension of the technology acceptance model: Four $\begin{array}{lllll}\text { longitudinal field } & \text { studies. }\end{array}$ http://dx.doi.org/10.1287/mnsc.46.2.186.11926

Venkatesh, V., \& Bala, H. (2008). Technology acceptance model 3 and a research agenda on interventions. Decision Sciences, 39(2), 273-315. http://dx.doi.org/10.1111/j.1540-5915.2008.00192.x

Venkatesh, V., \& Morris, M. G. (2000). Why Don't Men Ever Stop to Ask for Directions? Gender, Social Influence and Their Role in Technology Acceptance and Usage Behaviour. MIS Quarterly, 24(1), 115-139. http://dx.doi.org/10.2307/3250981

Venkatesh, V., Morris, M. G., Davis, G. B., \& Davis, F. D. (2003). User acceptance of information technology: Towards a unified view. MIS Quarterly, 27(3), 425-478. http://dx.doi.org/10.2307/3250981

Werrij, M. Q., Ruiter, R. A., Riet, J. V. T., \& De Vries, H. (2011). Self-efficacy as a potential moderator of the effects of framed health messages. Journal of Health Psychology, 16(2), 199-207. http://dx.doi.org/10.1177/1359105310374779

Wilkowska, W., Gaul, S., \& Ziefle, M. (2010). A Small but Significant Difference-The Role of Gender on Acceptance of Medical Assistive Technologies. HCI in Work and Learning, Life and Leisure. Springer Berlin Heidelberg. 82-100.

Yang, K. (2010). The effects of technology self-efficacy and innovativeness on consumer mobile data service adoption between American and Korean consumers. Journal of International Consumer Marketing, 22(2), 117-127. http://dx.doi.org/10.1080/08961530903476147

Yang, K. (2012). Consumer technology traits in determining mobile shopping adoption: An application of the extended theory of planned behavior. Journal of Retailing and Consumer Services, 19(5), 484-491. http://dx.doi.org/10.1016/j.jretconser.2012.06.003

Yang, S., Lu, Y., Gupta, S., Cao, Y., \& Zhang, R. (2012). Mobile payment services adoption across time: An empirical study of the effects of behavioral beliefs, social influences, and personal traits. Computers in Human Behavior, 28(1), 129-142. http://dx.doi.org/10.1016/j.chb.2011.08.019

Yap, C. S., \& Hii, J. W. H. (2009). Factors Affecting the Adoption of Mobile Commerce in Malaysia. Journal of Information Technology, 5(3), 24-37.

Yongmeng, Z. (2013). Determinants of the Adoption of Mobile Payment in China's 3G Market. (Doctoral dissertation, Sun Yat-sen University, China).

Zhang, J. (2009). Exploring drivers in the adoption of mobile commerce in China. The Journal of the American Academy of Business, 15(1), 64-69.

Zhang, J., \& Mao, E. (2008). Understanding the Acceptance of Mobile SMS Advertising among Young Chinese Consumers. Psychology \& Marketing, 25(8), 787-805. http://dx.doi.org/10.1002/mar.20239

Zhou, L., Dai, L., \& Zhang, D. (2007). Online shopping acceptance model-A critical survey of consumer factors in online shopping. Journal of Electronic Commerce Research, 8(1), 41-62. 


\section{Appendix A: modified survey questionnaire}

\begin{tabular}{|c|c|}
\hline Construct & Item \\
\hline Perceived Usefulness (PU) & $\begin{array}{l}\text { Using m-payment increases my performance to conduct financial transactions. } \\
\text { Using m-payment increases my productivity to conduct financial transactions. } \\
\text { Using m-payment enhances my effectiveness to conduct financial transactions. } \\
\text { I find m-payment useful in conducting financial transactions. }\end{array}$ \\
\hline $\begin{array}{l}\text { Perceived Ease of Use } \\
(\mathrm{PEOU})\end{array}$ & $\begin{array}{l}\text { I think learning to use m-payment system is clear and understandable. } \\
\text { Interacting and using m-payment system does not require a lot of my mental effort. } \\
\text { I think using m-payment system is easy. } \\
\text { I think purchasing what I want via m-payment is easy. }\end{array}$ \\
\hline Self-Efficacy (SE) & $\begin{array}{l}\text { I think that I can use m-payment even if there was no one around to tell me what to do as I go. } \\
\text { I think that I can use m-payment, if I had just the built-in help facility for assistance. } \\
\text { I think that I can use m-payment if someone shows me how to do it first. } \\
\text { I think that I can use m-payment if I had used similar technology before this one. }\end{array}$ \\
\hline Subjective Norm (SN) & $\begin{array}{l}\text { People who influence my behavior think that I should use m-payment. } \\
\text { People who are important to me think that I should use m-payment. } \\
\text { I think that university senior management will support the use of m-payment. } \\
\text { In general, the university has supported the use of m-payment. }\end{array}$ \\
\hline Image (IMG) & $\begin{array}{l}\text { I think that students in my university who use m-payment have more prestige than those who } \\
\text { do not. } \\
\text { I think that students in my university who use m-payment have a high profile. } \\
\text { I think that using m-payment makes me distinctive from others at the university. }\end{array}$ \\
\hline Output Quality (OUT) & $\begin{array}{l}\text { I think that the quality of the output I get from the use of m-payment system is high.. } \\
\text { I think that by merchandizing via m-payment, I will not have any problem with the quality of } \\
\text { (product, services, and information). } \\
\text { I rate the results from merchandizing via m-payment to be excellent. }\end{array}$ \\
\hline Demonstrability & $\begin{array}{l}\text { I have no difficulty telling others about the results of using m-payment system. } \\
\text { I believe I could communicate to others the consequences of using m-payment technology. } \\
\text { The results of using m-payment are apparent to me. } \\
\text { I would have difficulty explaining why using m-payment technology may or may not be } \\
\text { beneficial. }\end{array}$ \\
\hline Behavioral Intention (BI) & $\begin{array}{l}\text { Assuming I had access to m-payment system, I intend to use it. } \\
\text { Given that I had access to m-payment system, I predict that I would use it. } \\
\text { I plan to use m-payment in the next few months. }\end{array}$ \\
\hline
\end{tabular}

\section{Copyrights}

Copyright for this article is retained by the author(s), with first publication rights granted to the journal.

This is an open-access article distributed under the terms and conditions of the Creative Commons Attribution license (http://creativecommons.org/licenses/by/3.0/). 